\title{
A comparative study of in silico prediction of $\mathrm{pK}_{\mathrm{a}}$
}

\author{
C Matijssen \\ From 5th German Conference on Cheminformatics: 23. CIC-Workshop \\ Goslar, Germany. 8-10 November 2009
}

The ionization constant $\left(\mathrm{p} K_{\mathrm{a}}\right)$ is the measure of the strength of an acid or base in a solution. Most ligands act as a weak acid or base. Accurate determination of $\mathrm{p} K_{\mathrm{a}}$ is important as it can improve the pharmaceutical properties of a compound [1]. In general, charged compounds have better solubility, but are less effective in membrane permeation. Therefore, optimization of the pharmacokinetic profile of a compound can be performed by increasing or decreasing its ionization by changing functional groups. Another role for optimization of the charged group could be the interaction with its target. Changing the charge on the functional group could improve the interaction with its associated target and result in improved binding affinity.

Different methods have been developed for the computational determination of $\mathrm{p} K_{\mathrm{a}}$ values. These can be based on different methods such as QSAR [2] or quantum chemistry approaches [3]. These two methods differ considerable in terms of computational resource and hence, the time needed for a prediction. Depending on the number of ligands that needed prediction and time available, a choice for one method can be made.

A comparison between several $\mathrm{p} K_{\mathrm{a}}$ predictors (Pipeline Pilot, Moka, Epik and Jaguar) was made. All methods perform well when a diverse set of ligands which covers a range of $\mathrm{p} K_{\mathrm{a}}$ values is considered. However, when optimizing a series of compounds the influence of small changes to the molecule and its effect on $\mathrm{p} K_{\mathrm{a}}$ becomes more difficult to predict.

Published: 4 May 2010

\section{References}

1. Waterbeemd van de H, Gifford E: Nature Rev Drug Disc 2003, 2:192.

2. Milletti F, Storchi L, Sforna G, Cruciani G: J Chem Inf Model 2007, 47:2172.

3. Kinsella GK, Rodriguez F, Watson GW, Rozas I: Bioorg Med Chem $2007,15: 2850$

Cancer Research UK Centre for Cancer Therapeutics, The Institute of Cancer Research, 15 Cotswold Road, Sutton, Surrey, SM2 5NG, UK

doi:10.1186/1758-2946-2-S1-P37

Cite this article as: Matijssen: A comparative study of in silico prediction of $\mathrm{pK}_{\mathrm{a}}$. Journal of Cheminformatics 2010 2(Suppl 1):P37.

\footnotetext{
Publish with ChemistryCentral and every scientist can read your work free of charge

"Open access provides opportunities to our colleagues in other parts of the globe, by allowing anyone to view the content free of charge." W. Jeffery Hurst, The Hershey Company.

- available free of charge to the entire scientific community

- peer reviewed and published immediately upon acceptance

- cited in PubMed and archived on PubMed Central

- yours - you keep the copyright

Submit your manuscript here:

http://www.chemistrycentral.com/manuscript/

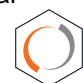
Chemistry Central
} 